\title{
Arab Identity in the poetry of Mahmoud Darwish and Lena Tuffaha
}

\section{*Dr. Maysa Abdel Aal Ibrahim}

\begin{abstract}
The issue of self-identity is an intricate and a multi-layered one. Any definition of the self involves a multiplicity of factors within and beyond the self. Those factors may be momentous to the shaping of the self to the extent that they become the lens through which the individual perceives him/herself. The two poets discussed in this paper, Mahmoud Darwish and Lena Tuffaha, have journeyed in a process of self-exploration in which they perceived their identities from the perspective of a lost homeland. This paper attempts to illuminate the poets' self-identities through the lens they perceived themselves. It examines their ongoing process of revisioning with regard to their selfconception. The paper draws on several self-theories which help illuminate the different facets of their self-identities in relation to their homeland and makes use of the motifs of time and place in the discussion.
\end{abstract}

Key words: Self-identity, I- positioning, homeland, time, trauma, colonization, Arab identity.

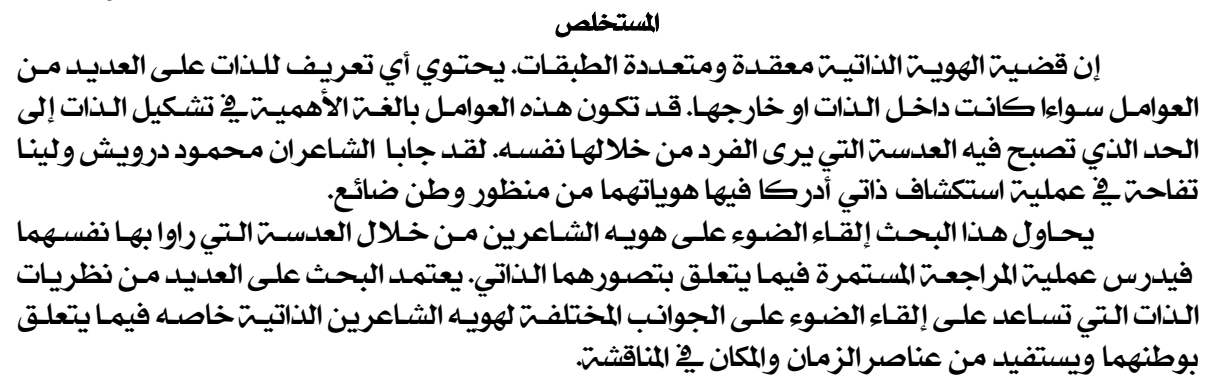

\section{Introduction}

The self is by definition always a complexio oppositorum (a collection of opposites)-Carl Jung

The question of identity is a broad concept, far too broad to be dealt with in a research paper, or to be comprehended in real life. This is evidently due to the profundity of the self, and to the multiplicity of factors that go into its constitution. The self does not only live in a community that helps shape it and occupies indeed a considerable part of

\footnotetext{
* Assistant Professor in the Department of English Language and Literature, Faculty of Arts, Tanta University
} 
it, but it also lives in time and place which are factors that impact the very fabric of the self.

In this paper I attempt to explore the identity of two poets who share a homeland and a historical background, yet who live in different locales and circumstances -Mahmoud Darwish, 1947-2008, the renowned, prolific Palestinian poet, and Lena Khalaf Tuffaha, 1975-, the Palestinian, Jordanian/ American poet who lives in Redmond, Washington, Seattle. Those two poets do not only share a history and a homeland, but they also share a similar sensibility towards their lost homeland and towards their self-conception. The aim of this paper is to illuminate the identity of those two poets in the light of the time and environment in which they lived.

I have investigated theories that cover the topic of self-identity from different perspectives, namely from the psychological and sociological points of view; I have also investigated theories which throw light on the identity of the colonized and theories of national trauma, since the two poets studied in this paper have gone through the pains of losing a homeland and of being colonized.

The theories I draw on support the concept of the multiple nature and the dynamic change of the self in life. One example is Dialogical Self Theory, which affirms that the self is a micro-society composed of many inner selves that are in constant dynamic change, a notion termed Ipositionings, within the self as well as towards others. Social Identity Theory, to give another example, asserts that the self swings in a continuum of the personal and the collective self, therefore feels and acts at the personal or collective level in different times and situations.

Those theories have made me read the poems of Mahmoud Darwish and Lena Tuffaha from a different perspective. They have given me insight into how others, or to put it more precisely, the other, occupy, or occupies, part of their identities. In some of the poems I deal with here, the poets engage in a dialogical relationship with the other; Dialogical Self Theory has illuminated the role of internal and external I-positionings and the significances and implications of the shifts they make. In other words, 
those theories have shed light on Darwish's and Tuffaha's identities in a more sophisticated and detailed manner.

\section{Hubert Herman's Dialogical Self-Theory (DST)}

This theory proposes that the self is a society on its own composed of a multiplicity of selves called I-positions. Those I-positions interact within the self in dialogical relationships to inform, challenge, pacify, demean, overrule, etc., one another in the same way individuals interact in a society (Assessing and Stimulating a Dialogical Self, 2). In more scientific terms, "DST suggests the self is organized as a dynamic landscape of autonomous I-positions that continually influence each other through dialogical interchanges...Just as in any social system, the internal society of I-positions is diverse and political. Some I-positions are dominant and overpowering whereas others are more quiet and subdued. Some tend to be supporting, caring and confident, while others tend to be fearful, derogative and criticizing" (2). However, because the self lives in an outer society, it poses itself towards others in dialogical relationships also by means of I-positioning. An I-position is the stance an individual takes towards another in a dialogical relationship, or the stance a self, among the multiplicity of selves, takes towards another. The self is therefore involved in two types of dialogical I-positioning: internal and external. Both positionings are neither static nor independent of one another. The 'I'moves back and forth among different, even opposed positions, which interact much like individuals do, learning from each other and creating new meanings (Intro xv).

William James, American philosopher, psychologist and originator of the concept of the dialogical self, distinguishes between 'I'(self as subject) and 'me'(self as object). James holds that the 'I'corresponds to the 'self-as-knower' - as thinker and causal agent, and the 'Me'to the 'self as known'(qtd. in "Construction and Reconstruction" 97). The "I'is basically a continuous self that is distinct from others by a sense of individuality which stems from the subjective nature of the self (97). The 'Me, 'on the other hand, is the different aspects of the self, namely the physical, the social and the spiritual (103). James 'concept of the extended nature of the self suggests that the self is extended not only to whatever it can call mine, but also to the environment, to the other. In the tradition 
of William James, the dialogical self is not an encapsulated self which lives within its own boundaries and perceives the world as outside the self and the other as "outside the skin" (98); on the contrary, the dialogical self is "other-inclusive" because it is "populated by the voices of other people [and is] decentralized with highly open boundaries" (90). Drawing on James'ideas, Hubert Hermans, who postulated DST in cooperation with others, suggests that since the 'I' extends to include the other, the identity question, "Who am I?" should be rephrased as "Who am I in relation to the other?" Hermans also holds that self-knowledge increases when relationship with the other is admitted and explored as part of the extended self (104).

There remains one last aspect of DST to be discussed, which is the collective self. The term I-position covers positions which stem from the 'we'experience. People from different cultures and different groups within the same culture may locate themselves at either end of the large scaled continuum of the I-We experience, depending on the positions in which they are involved. (105).

\section{Erik Erikson's Theory of Psychosocial Development}

German-American psychologist and psychoanalyst Erik Erikson postulated his psychosocial theory of identity and human development around eight stages which an individual goes through in his life from infancy to old age. What is unique about Erikson's theory is that each stage is considered a resolution of conflicting psychosocial and biological forces, which, if the individual smoothly undergoes and successfully reconciles, $\mathrm{h} / \mathrm{she}$ will come forth from the stage with an acquired virtue to be carried to the next stage. Failure to do so leads to a future problem, which however is remediable in the ongoing process of human growth and development (Erikson 110). Each stage is therefore accompanied by "critical tasks that enhance and guide the individual's sense of self and ego identity," (Sonia 208) and involves what Erikson calls an "ego crises."

Erikson stresses the momentous importance of adolescence in ego formation and self-identity; he holds that this stage, which he calls a "psychosocial moratorium" during which an individual explores a range of options without making commitments, is "a crossroad or a bridge 
between childhood and adulthood." He considers this stage a period of "role experimentation" and "final choices after all identifications from earlier periods are integrated" (Sonia 142). For him, the adolescent or the young individual's mind is an "ideological" one in search of ideals or ideas and in need of a sense of "inspiring unification or tradition" (Erikson 130). Should the identity crises be resolved at this stage, the positive outcome is that the individual feels at one with him/herself and develops "a sense of belonging to a community that itself has a past, a present, and a future" (142). The question here is how far the community may further, support, or enhance the individual's rite of passage and may confirm his/her ideologies. As Erikson puts it, "Indeed it is the ideological potential of a society which speaks most clearly to the adolescent who is so eager to be affirmed by peers, to be confirmed by teachers, and to be inspired by worth-while ways of life" (Erikson 130). On the other hand, if a society fails to do so, the young individual would resist with all his/her might (130).

\section{Social Identity Theory}

Postulated by social psychologists Henri Tajfel and John Turner, social identity theory holds that the social groups with which individuals identify inform their self-image and self-esteem (40). In the process of organizing and making sense of the social world, individuals categorize the social environment into social groups that "provide a system of orientation for self-reference". The groups to which an individual ascribes him/herself are called "in-groups" and, conversely, those to which an individual has no sense of belonging are perceived by the individual as "out-groups". To achieve a positive social identity and self-image, the individual must perceive his/her in-group as "positively differentiated" from, i.e. superior to, the relevant out-groups (40). This process explains the psychosocial phenomena of favoritism and discrimination: to heighten self-image, individuals tend to underscore the positive characteristics of their in-groups and discriminate against out-groups.

\section{Trauma Theory}

Cultural or national traumas occur when people of a nation, or "members of a collectivity," feel they have been "subjected to a 
horrendous event" that has shattered their lives and left negative imprints on their collective consciousness, identity and memory in irremediable ways (Alexander1).

According to Arthur Neal, collective traumas have a powerful impact on national identity. In some cases, national traumas may result in a sense of unity among the people of the nation affected, whereas in others they may lead to the fragmentation of the society (qtd in Alexander 8).

It is interesting to note that people vary in their responses to collective, national traumas. Some are keen on keeping record, on remembrance, on taking responsibility and on finding remedies, whereas others deny the trauma and go about their ways in a state of unwillingness to remember and a willingness to forget (Alexander 7-8). However, it is only by revival of memory that healing can take place. "The aim is to restore collective psychological heath by lifting societal repression and restoring memory" (Alexander 7).

\section{Analytical Study of the Poetry of Darwish and Tuffaha Homeland}

A keyword to understanding the poetry and identity of the two poets discussed in this paper, the word "homeland" is as vast as an ocean in its meanings and significances to them, which makes the task of exploring it, though interesting, immensely overwhelming. I believe the pain of exile and estrangement in their own land and away from it has led both poets to love and to cherish each grain of sand, each drop of sea water, each olive twig, each grain of wheat, etc. in it.

In "Exile is so Strong within me, I may bring it to the land," an interview with Helit Yeshurun, founder of the Israeli cultural review Hadarim, Darwish explains:

The earth is my first mother. From there I was born and it is to there that I will return. The whole circle of human life is in it... Since the earth was taken from me and I was exiled from it, it has turned into the source and address of my spirit and my dreams... It is both the source of poetry and the material of poetry (Yeshurun 50). 
Darwish's lost Palestine is reminiscent of a lost Eden; Darwish often speaks of Palestine in terms of a paradise. When he writes about the lost Andalusia, he does so with an eye on his homeland. The lost Granada, for him, represents "a lost ideal, a dream," (Wasserstein 115) which also stands for the lost Palestine. On the beauty of Granada Darwish writes, "But Granada is gold, / silken words embroidered with almonds" (qtd. in Wasserstein 115).

This explains how the "earth" has turned into the source and address of his spirit and dreams. Palestine is a land of beauty and history, and is also a lost land. Darwish's title of his selected poems, "Unfortunately, it was Paradise," delineates the idea. The word earth signifies Darwish's bond with the land in its most basic elements, the earth. As much as it is a simple word, it is an all-encompassing one because it pertains to place in its most elemental, yet concrete sense. In addition, the fact that the earth is his first mother before his own biological mother manifests the inseparable bond between them. It takes precedence over the biological mother because the latter gives birth only and is not responsible for the death of her children, whereas mother earth, which "contains the whole circle of human life", according to Darwish, gives birth and contains death. In his poem, "My Father" Darwish writes:

My father once said

He who has no homeland

has no grave on earth

"I've made a shroud of belonging / a refugee tent pitched in the mud of memory." - Lena Tuffaha

By comparison, Lena Tuffaha, an Arab-American of Palestinian, Jordanian and Syrian heritage, writes from a bilingual and bicultural position. Nonetheless, her poetry, like Darwish's, is steeped in love of her homeland and of her native language, Arabic. Like Darwish too, her Arab identity is the focal point of her life and writing. "Being Arab is where my story begins," she says (qtd in Farhat). Though an American citizen, for her, "home is often places where... [she's] known fully and in [her] native 
language" (Hughes). Nonetheless, because as a child Tuffaha was deprived of her real homeland, Palestine, therefore "traveled and moved a lot" in the Arab world with her parents, she often speaks of the "nowhere homeland" and of the "relief that the nowhere homeland can provide from some of the burdens of love and belonging" (Hughes). Having said that in prose, on the one hand, Tuffaha's poetry, on the other, is a testimony of "love and belonging." Her work, like Darwish's, expresses a deep longing for a lost land and a lost past. Many of her poems are mini portraits of life in her homeland, her much cherished memories of family, love, food and, undoubtedly, of the beauty of natural landscapes. "The dialects and wedding songs and rituals of grieving and the fragrances of our food and seasonal rituals are the fabric of my youth," she says (Hughes). And in her poetry, there is always the longing, "the longing / for what is no longer here nor possible" (from her poem "Linger," "The James Franco Review" p.16). It is noteworthy that the longing for an idyllic homeland and past recurs time and again in Darwish's work, as in the poems he wrote to his mother and in a poem entitled "Yearning," to give only a few examples. At the other end, Tuffaha's work also dwells on the grievances of the Palestinian people and on the horrors that take place in her homeland.

If the previous paragraphs gave the reader a bird's eye-view of how Darwish and Tuffaha perceived their homeland, the following is a practical analysis of their poetry. Darwish's early homeland poems manifest a profound love for and interconnectedness with the land. They manifest an identity that is rooted in the place, particularly in its nature; however, it is one which also emanates from a wounded national identity and from the position of the colonized. In "Identity Card," one of Darwish's earliest poems and one that has brought him fame and earned him the epithet, "Poet of the Palestinian Resistance," Darwish asserts his Arab identity in the face of the Israeli occupier and assailant as a defense mechanism against his humiliation and bombardment. The assertion of the poet's position as owner of the land is a means of protecting his image, both internally and externally. "A colonized person must constantly be aware of his image, jealously protect his position," the French West Indian psychiatrist and political thinker, Frantz Fanon, remarks in his book, 
The Wretched of the Earth (Fanon, Foreword, ix). The defensive, at times defiant, voice in the poem may be attributed to what Fanon describes as the anger and hostility the colonized feels towards the colonizer. In Fanon's words, "the defenses of the colonized are tuned like anxious antennae waiting to pick up the hostile signals of a racially divided world" (Fanon, Foreword, ix).

The poet refuses to identify himself in terms of a document- an ID card- and asserts that his identity is deeply rooted in the land. A sense of primordial bond between the two entities, the land and himself, prevails throughout the poem.

The deep interconnectedness between himself and the land manifested in the lines, "My roots were entrenched before the birth of time/ before the opening of the eras/ before the cypress and the olives.." renders the poet a tree, a plant, a twig, a rock or a stone that is thousands of years old in Palestine. Darwish seems to be saying: I am here before the birth of everything; the land and myself are one; in fact, I am the land- so what is the use of an ID card? (Splinters of Bone: Poems pp. 13-14.)

DST asserts that "both internal and external positions can have the quality of I-positions;" that is, the other may be "conceived as another subject" or another "full-fledged I," as Mikhail Bakhtin, the Russian philosopher, puts it. Indeed, according to DST, "we can identify with another person, animal, or even an object or with nature," and "this identification can reach the point that the other is seen as part of an extended self" (Assessing and Stimulating a Dialogical Self, 7-8). In the light of DST, Darwish identifies here with nature to the point that it is seen as part of his extended self.

The poem draws a picture of the humbled, dispossessed Arab who toils in his own stolen land, yet whose pride and dignity emanate from the primordial bond between him and the land. Thus, notwithstanding the fact that he lives in a hut made of wooden beams, in a disarmed, forgotten village, and that his parents and ancestors were peasants, he is proud of his Arab identity which he derives from the land. 
It is noteworthy that Darwish is thinking and acting here on his national level of self; in other words, his sense of who he is is defined in terms of 'we'rather than 'I. 'His response to the Israeli authorities is the response of the collective self of his community and his self-description is not a personal but a social national one; the Arab in the poem is the ordinary Palestinian citizen under the Israeli occupation.

Social Identity theory maintains that "social groups and categories stand in status relation to one another and are often in competition for resources, rights and power" (Hogg and Abrams 4). In the normal social context, it is natural for one group to be resourceful, powerful and dominating, and for the other to be subordinate owing to low status. In this context, the calamity of the subordinate group is even more vehement owing to the colonizer/colonized relationship between the two groups. Here Darwish belongs to the low-status subordinate national ethnic group that is overpowered by the other. However, his low status is not a born-with facet, rather an outcome of the other's oppression, a fact which explains his indignant attitude towards the other. Despite his poor status, he does not supplicate for charity at the door of the rich colonist; his dignity and humanity are more important to him than the riches of the world.

Darwish's ID Card is a perfect example of internal and external relationships in DST; in fact, it is an exposition of most of the major concepts of the theory. The poem is a real, or imagined, dialogue between Darwish and the silent, rather the silenced, marginalized other whose voice is not heard, nor is his viewpoint.

In real life, as well as in the world of Dialogical Self-Theory, social dominance is a core fact in dialogical relationships. Speakers can communicate comprehensibly only if they take turns as speakers and listeners (DST and Increasing Multiplicity, 5). When one person, or one voice, dominates the other so strongly in a dialogue that the latter hardly finds the opportunity to express his/her thoughts, dialogue turns into monologue (7). ID Card blends both dialogic and monologic facets in a fashion that suppresses and marginalizes the other. 
When the poet gives an extensive depiction of his life, his past and present, as well as of his physical appearance, the poem tends to be monologic; however, when he hurriedly goes back to address the other in the refrain, "does that anger you?" he turns into the dialogic mode. The last two stanzas are purely dialogic because the poet is confronting the other with the truth of his assault and land robbery. The imperative line in the last stanza, "Write down on the first page," is a clear command that turns the tables against the Israeli officer and places him in a subordinate position. All in all, in the duality of dialogue and monologue, the other is always marginalized as aforementioned.

Throughout the poem Darwish, in line with DST, shifts his Ipositioning in a very dynamic way. Each stanza takes us to a different scene and to a different I-position towards the self and towards the other: from a portrayal of family to labor to origins and roots in the land, to physical appearance, to village and companions, then finally to the assailing other. In each of the scenes Darwish takes a different stance; he is the oppressed, yet patient, citizen, prideful, yet humble, without a title, yet morally and physically strong, patient, yet to limits. In all of those Ipositions Darwish is exploring his identity, not only from a selfperspective, but also from the perspective of the self in relation to the other.

A poem with similar sentiments, though conceptually and vocally more personal than "Identity Card," in which Darwish asserts his identity through a deep bond with the land, is "Passport." In this poem, Darwish refuses to identify himself by means of a passport, which does not reflect his real image, nor identity. His relation to his homeland is far deeper and nobler than a distorted, misguiding document, particularly that it is checked by a harassing other, who, by some tragic turn of fate, happens to rule the land and to become "master." If the poet was not recognized in his passport photograph by "the master," he was embraced and accompanied to the airport by the entire land, by its living creatures and its objects and by the people who know and love him immensely. Ironically, all those loving witnesses are not on the passport, an unreal identity mirror! In this poem, Darwish juxtaposes two realities: the first is 
his present and unreal image, one in which he is not recognized by the authoritative stranger, "Stripped of a name and an identity." It is a cruel, bleak reality which does not reflect his true self, although it is one that he has to live and endure. The second is his past, real and eternal self; it is a secure, idyllic reality where he is known and loved by his countrymen, by the land itself and by its living creatures. The argument is one in which the land owner, who has been robbed of his rights of sovereignty of the place, asserts his identity in the land.

All the birds that followed my palm

From my forehead cleaves the sword of light, from my hand gushes the river's water, all the hearts of people are my identity, so take away my passport!

The image of the gushing of the river's water from his hand and the cleaving of the "sword of light from [his] forehead" speaks of a primordial bond between him and the land in a manner that is even more powerful than in ID card. The beauty of the image emanates from its archetypal aspect; "my hand" and "my forehead" here signify man in the abstract sense, rather in the historical sense. The poet and nature are like equal partners standing together in solidarity, firm and faithful in their bond.

The recurrent question, "Who am I?" in the poetry of Mahmoud Darwish attests to the dialogical relationship between parts of the poet's self with respect to his identity. The fact that this basic question recurs over the years in the poetry, old and new, of a colossal poet like Mahmoud Darwish, a chronicler of both personal and national history, denotes an on-going process of identity assessment and a constant shifting of Ipositions, both internally and externally.

The young poet who insisted on his Arab identity has traveled, lived in different parts of the world and developed a "polyphonic consciousness," as Mustafa Marrouchi points out (qtd. in Sazzad 217). Darwish admits his polyphonic consciousness when he points out to Yeshurun, that he is "a son of all the cultures that have passed through the land- the Greek, the Roman, the Persian, the Jewish, the 
Ottoman...[he is] the son of all these fathers" (qtd. in Yeshurun 52). In tune with DST which affirms the identity of the individual in terms of his/her relationship to the other, the identity question in Darwish's poetry shifts from the earlier, "who am I?" to the later "who am I in relation to the other?" Darwish's poem "Who am I after the Night of the Stranger?" testifies to this truth. When Yeshurun asks him who he is after the night of the stranger, Darwish, in line with James'concept of the extended nature of the self, answers: "I am not myself. If there is no stranger in my identity, I don't recognize myself. I can be defined only through the dialectical relationship between myself and the other. If I were alone without my fellow man, what would I understand? I would be filled with myself, my entire truth, without dualism" (68).

Darwish, who was burdened all his life with a momentous sense of responsibility towards his homeland and its liberation, whose sense of national identity had overshadowed his personal identity at one time, was, in the later years, in quest of his own personal identity as a poet and as a global citizen. Therefore, identity became "not a heritage of the past, but the offspring of birth / ... a creative act of its owner.". "Antithesis." Journal of Arabic Literature, pp. 50-51.

On the dynamic process of change discussed above with regard to Darwish, it is interesting that the poet is himself fully aware of the process. He illuminates this when he says:

Is the I-that-was the I-that-returned? Even Ulysses didn't return as the same man. The sea changed him. The sea and the years. He didn't find the same house. He didn't find the same Penelope. You don't find yourself twice. Every day you are a different man (qtd. in Yeshurun 67).

However, in tune with Erikson's concept of an individual's identity as a sense of self-sameness through time, Darwish's profound love for his homeland has never wavered. The shifting of I-position in his later years has geared him towards Edward Said's advice: "carry your homeland wherever you go, and be a narcissist if need be." (Antithesis) Darwish might have followed the first part of the advice but I don't believe he ever developed into a narcissist. 
In a nutshell, Darwish's poetry is a testimony of a life-long journey of a quest for identity. Regardless of the shifts and turns his sense of self-identity has taken, his life and poetry exemplify Erikson's words: "indeed, in the social jungle of human existence there is no feeling of being alive without a sense of identity" (Erikson 132).

Lena Tuffaha's love of homeland permeates all her work too. Like Darwish's, her poems abound in nature imagery, and the bond between land and self which characterizes Darwish's poetry is also prevalent in her own. The difference between the two poets is that whereas Darwish's imagery tends towards vastness of landscapes, Tuffaha's lens is narrower and tends to capture more minute locales.

In a poem entitled "Immigrant," Tuffaha is in her uncle's car, leaving Amman behind, a city of her childhood memories, and is heading for the airport, for the US and for the unknown. Tuffaha is "driving away from impending war ...on the magic carpet of her navy blue /US passport" that will carry her supposedly to "safety" and ironically to

the place where the planes are made

and the place where the President

will make the call to send the planes

into my storybook childhood,

over the seven hills,

next door to neighbors who will now

become refugees. (Water and Salt, pp.22-23)

Tuffaha feels as insecure as a motherless child because, though she is "driving away" from physical hazard, she is leaving her homeland behind with all it stands for: love, warmth, memories and emotional security. She is also leaving a place in which she finds her true identity.

We are driving and I

am not safe

driving away from

myself and everything I know 
For Tuffaha, self and homeland are one entity since driving away from homeland is equivalent to "driving away from/self," and from "everything [she] know[s]." Homeland is a source of security because it informs her self and mind; it is all she knows and all she needs to know. It also contains her soul which is deeply rooted in the place, in its nature, in its hills and trees, a fact which makes leaving it "undo" her young life. The poet is in a deep spiritual bond with each spot in the landscape of her homeland, an extension of the landscape of herself.

My young life is coming undone

on the road behind me

where I know all the names in Arabic

rumman, saru, zayzafoon

and I know the spot on each dry hilltop

where the crimson poppies return in spring.

In another poem "Upon Arrival," which captures her soul and identity as also rooted in the place, Tuffaha provides a poetic answer to the Israeli government which demands the Palestinian immigrants to state the reason for their visit to Palestine, or Israel, upon their arrival.
You will need to state the reason for your visit
Don't say because I want to walk down old roads
and caress stone walls the color of my skin.
You will need to state the reason for your visit.
Don't say because the olives are ready for harvest
and I will coax the fruit from the trees,
press it into liquid gold. (Water and salt, p15)

In this poem, Tuffaha is posing herself in a dialogical relationship with an imagined other; she is "placing herself vis-a-vis somebody else in the literal, societal space, and at the same time, towards [herself] in the metaphorical space of the self" (Assessing and Stimulating, p. xvii). However, the dialogue involves more than two people. The 'you'in the poem is actually a collective 'we', albeit seemingly addressed to an ingroup person. The poet is addressing here the whole 'we'in-group - the 
Palestinian immigrants - and in the meantime she is positioning herself towards the other and is including him in the dialogue. The first refrain, "You will need to state the reason for your visit," though addressed to the in-group, is a derogative I-positioning against the other who asks her and her total in-group to state the reason for their visit to their homeland upon arrival. The second refrain, "Don't say because" is purely addressed to the in-group, however with the imagined other in the background because here too there are ironic, derogative implications expressing her contemptuous I-positioning towards the other every time she gives the stark clear truth of the reason for her visit, which implies the notion :"this is my homeland." The fact that the words, "Don't say," are written unitalicized, whereas the following sentences, the reasons for the visit, are italicized enhances the 'we'in-group effect and bonds the group as an integral unit.

Tuffaha's poem exemplifies James'concept of the "extended nature of the self," which is "other-inclusive," and Hermans 'belief that not only one's "mother" belongs to the self but even one's "enemy." The enemy is lurking everywhere in the poem, and though not directly addressed, is pervasive. He is more than a third party in a dialogue; his salience is unquestionable.

Another aspect of I-positioning in the poem is the internal positioning of the poet towards her homeland. The lines in which she gives the reasons for her visit, for e.g., "caress stone walls the color of my skin," and "coax the fruit from the trees," express deep affinity with her homeland.

It is interesting to note that the poem is subtly based on the same argument as in Darwish's two above-mentioned poems. Just as Darwish's poems are an answer in the face of the harassing Israeli officer, who requires his ID card and passport, this poem is a response to the Israeli government which requires of Palestinians living outside Palestine, or Israel, to "state the reason for their visit" once they arrive in the land. In Darwish we see a cry in the face of the enemy, a bold, defiant voice rejecting the control and harassment of an other, of a stranger in his own 
country. In Tuffaha's poem, on the other hand, a quieter voice prevails; nevertheless, it is an ironic voice which serves the same purpose as in Darwish: who are you to ask me for documents and justifications in my own homeland?

The poem exemplifies Tuffaha's love for all the detailed aspects of her homeland. The first reason Tuffaha gives for her visit suggests a deep longing for a missed homeland, one that is similar to the longing for a missed beloved. In the words, "to caress stone walls," we see the encounter of two lovers who have long been apart. The fact that the stones are "the color of [her] skin" make the longing all the more justifiable because those two lovers are akin in semblance and, most probably, in soul. The lines, “Don't say because I want to walk down old roads/ and caress stone walls the color of my skin" are, at large, a stark assertion of her identity that is deeply rooted in the place. The first half of the line, "I want to walk down old roads" points to the affinity she has with the place since childhood, and "the color of my skin" reaffirms that affinity.

Each stanza is dedicated to one reason the poet would like to visit her country and all reasons impart a sense of belonging, as well as of longing for an encounter with the beloved. They also impart a deep rootedness in and interconnectedness with the land. The image of "coaxing the fruit from the trees" and "pressing it into liquid gold" is a milder version of Darwish's "from my hand gushes the rivers 'water." Here too we see man giving life to nature, albeit by way of coaxing it and making it yield to him. The image, particularly the word "gold," speaks of a lost Eden and is reminiscent of Darwish's aforementioned depiction of Granada, "But Granada is gold..." For both Darwish and Tuffaha, Palestine is a lost Eden; both of them are in love with the beauty and historicity of the land.

Time is a major motif that helps in an understanding of the identity makeup of the two poets. The natural flow and progressive movement of time from past to present and future in human life is disrupted in the lives and poetry of Darwish and Tuffaha. This is due to the toppling of their 
world upon the advent of the Israeli colonizer. Sazzad points to the idea that the colonial voyages have led to an interruption in the continuity of the colonized people's past. She says: "The colonial voyages resulted not only in the subjugation of the 'others 'but also in the interruption of the continuity of their past. The colonized people were deprived of a secure sense of identity anchored in a discernible history..." (Sazzad 191). In other words, the idyllic past has not continued on to blend with a secure present. There is a rupture between past and present, a chasm, an abysmal incurable wound. How can one wake up to a present of a world that has toppled, crumbled and left one in desolation amidst the rubbles of history, and yet reconcile with that? The suddenness with which the scene has changed in Palestine, particularly in the life of Darwish, was incurably traumatic. It is no wonder that there would be a refusal of a harsh, desolate present, one which the poets cannot identify with, and a deep longing for the past.

In her poem "Immigrant," Tuffaha dreams of a reversal of time. The imagery throughout the poem depicts a resented breach and severance with the past:

I am watching the road unravel

behind us like a ribbon of dust

The spiral movement of the ribbon, as well as the word "dust," impart a sense of disappearance into thin air. The road behind her is the road of her past life that is now gone into oblivion and is not to be traced anywhere just like dust particles flown in the air. This idea of the total disappearance of the past is, ironically, on par with Zionist ideology that has worked relentlessly for a total erasure of the history of the Palestinians.

The poet then takes us on a journey through the pages of her "story book" of the idyllic past. She draws a picturesque scene of beautiful Amman as it unfolds behind her from a child's viewpoint. The child is herself that refuses to grow, would rather be transported through some miraculous time machine to the past and be forgotten on the pages of her book. 
The fact that the poet is leaving her past behind brings along feelings of loss and insecurity. The word "undone" in "My young life is coming undone/ on the road behind me" makes her past a non-existent thing that is not only irretrievable, as all past is, but also that has fallen into an abysmal chasm of oblivion- a chasm that she will never be able to bridge. Tuffaha is closing one chapter of her life, and is starting a new one; in fact, she is starting a new life altogether. Her future life is severed from her past in an almost traumatic way because she is leaving her self and identity behind and is embarking on a new self and a new identity. The line on the whole expresses feelings of resentment and grief over loss of the past.

The poet finally draws her feelings of yearning for the past to a climax in the last stanza when she beautifully says:

I want to float through the window

And run towards yesterday

Those lines stem in large measure from a deep longing to live in the past, to "turn the past into the focal point and to marginalize the present" (Hamza 167). This is owing to the fact that the present represents loss and deprivation, whereas the past is seen as idyllic, as a state which the poet wishes to live in forever.

This confusion with time and what it has inflicted on the poet's personal life and on the lives of the Palestinians at large is best expressed in Tuffaha's group of poems which she dedicates to the verb "Kaan" and "her sisters." The verb "kaan" and "her sisters" in Arabic are a group of verbs which denote the past and all forms of the present, for example, remains, still is..., etc. In those poems, Tuffaha tries to come to terms with time, to grapple with its various meanings, implications and the changes it had brought. Those poems beautifully chronicle the aftermath of the Israeli occupation of Palestine and the collective trauma the occupation has caused to the Palestinian nation at large. They portray the ruins the Palestinians are left with, the shattered lives, the estrangement, exile, alienation, displacement, dispossession and humiliation they suffer in their own homeland. What is interesting is that Tuffaha does not blame 
time for her predicament; on the contrary, she sympathizes, rather empathizes, with it. Time is more an object of pity in those poems than anything else. In the poem, "Notes on the Nature and Implications of Kaan," a title that speaks to the multiple implications of the past, the poet attempts to set an equilibrium between past and present and to ignite some hope for the future. She dwells on the concept of nihilism- a core fact in the lives of the Palestinians- when she invokes kaan's sister "mazaal:"

One of kaan's sisters is Ma zaal.

Ma negates and Zaal says gone, vanished.

And together they stand, intertwined, negation

And vanishing and we Arabic speakers must trust they mean

No end no end no end

Even when the land is lost.

It did not vanish there is still time. (Michigan Quarterly Review p. 219)

It is interesting to note that the verb "mazaal" in Arabic, which is a compound word, means "there still is," so if we put it in the context of time it would mean "there is still time," as the last line in the poem reads. However, Tuffaha reflects her sentiments of loss and negation on the word, thus chooses to divide it into its constituent parts, 'ma 'and 'zaal,' both of which mean negation, 'ma 'meaning not and 'Zaal 'meaning gone. When towards the end of the poem she shifts her I-position, both internally and externally, and the optimistic self becomes dominant, she decides to have faith in the future, thus sets the parts back as one compound word to imply their original meaning, "there still is."

In another poem, "Kaan's Sister Saar," the poet draws a picture of the present Palestinian predicament by means of delineating on the verb "saar," one among several of the verbs called "Kaan's sisters," which means "has become." In the poem, "Saar," who represents the present, is depicted as a young little sister ignored by everybody; she is a lonesome figure who deserves pity because she spends most of her time scavenging in the midst of the rubbles of the now. Nobody pays attention to her, "nobody takes this sister seriously," partly because of her simple, one syllabled name "Saar." 
Saar is, in fact, an embodiment of the "voices ... who call for commemoration, for remembrance of the disappearances and the torment" (qtd in Alexander, 7), whereas those who do not "take her seriously" are the ones who, out of fear, want to forget the past, to deny and "repress the experience of trauma itself" (qtd. in Alexander 7). Those people "make it their business to act as if nothing had happened here;" Jelin and Kaufman call them the "bystanders of horror" who claim they "did not know" and "did not see" (qtd. in 7). However, "Saar" is committed to remembrance and her profound rootedness in the present is in fact an act of faithfulness to the past with all its glory. She is overwhelmed by the shabby, disdainful present, and

All day long she's grasping

At stones and chasing after checkpoints (Michigan Quarterly Review p. 222).

Much though this sister is not given attention, as "people forget/ or walk around as if they had forgotten," "Saar" assumes an important role in the lives of the people around her because she is the one to foretell "what will survive" and "who we mourn."

There is no end to elaborating on those poems because they are a beautiful and figurative embodiment of the poet's perspective of time as well as of the traumatic experience the Palestinians are currently living. In them we hear the collective voices of Tuffaha's community which are part of her individual self and, in Hermans 'words, "transcend it as part of the broader historical and social community" (Construction 105).

This disrupted relation with time, particularly the rupture between past and present, evident in Lena Tuffaha's poetry, finds its epitome in Mahmoud Darwish's "The Owl's Night." Depicting an existential image of the tragic absurdity of the Palestinian situation, of a people uprooted from their past, Darwish is grappling here with the concept of time among other existential concerns. He topples all human understanding of time and, in fact, of place too. The breach between past and present is part of the picture he draws of a shattered, traumatized society, rather a traumatized "collectivity", who has lost its sense of national identity, and 
the bond that has once brought its individuals together as a nation. This scattered community is depicted as living a nightmarish reality because it has fallen upon a time and place it neither relates to, nor recognizes.

There is here a present not embraced by the past.

we saw absence piling up its chosen objects

and pitching its eternal tent around us.

There is here a timeless present,

No one remembers how we went out the door

like a gust of wind,

and at what hour we fell from yesterday, and then

yesterday shattered on the tiles

in shards for others to reassemble into mirrors

reflecting their images over ours.

There is here a placeless present.

Perhaps I can handle my life and cry out in the owl's night:

Was this condemned man my father who burdens me with his history?

(Why Did You Leave the Horse Alone? p. 22).

As in Lena Tuffaha's work, time is depicted in terms of a present that is totally dissociated from the past. The refrain, "There is here a present not embraced/by the past," is repeated twice in the poem. Owing to the dramatic change of scene that occurred in Darwish's homeland, the past is essentially severed from the present, and the latter stands in isolation, solitary and unattached to anything but itself, like an iceberg that has disconnected itself and drifted off in deep waters. Then in each of the following stanzas, the poet gives an adjective to the present; at one time it is a "timeless" present, at another it is a "placeless" present and finally it is a "transient" present. If this present is neither attached to time, nor to place, and, naturally, it is a "transient" present because it is not attached to the future, then it must be in a state of suspension in the nowhere just as the group of people living it are. It is a present that reflects the poet's questioning mind over ideas of loss, absence and negation. 
The present is dissociated from the past because the latter is shattered on the tiles and, ironically, is being collected by another who wishes to create his image. What augments the state of up rootedness of this present scattered collectivity is the fact that they have gone "out the door like a gust of wind" and that they have "fallen from yesterday" and that no one even remembers "how [they] went out the door" and when or "at which hour" they have fallen. They are in a state of loss of memory. The fact that they have gone "out the door" signifies that they once had a home where they lived and "like a gust of wind" depicts not only the speed at which they fell but also the image of falling out into the nowhere, into nothingness.

In this absence of time and place, the past emerges when Darwish poses his existential question:

Was this condemned man my father

Who leaves me the burden of his history?

Those lines beautifully express Darwish's feelings of responsibility for his dispossessed, uprooted community. Does he blame his father for bringing him up as a man? Does he blame his father for bringing him to life, then bequeathing him the responsibility of a whole community? The word "condemned" enhances the sentiments of resentment the poet bears for having to bear such a monumental responsibility.

It is interesting to note that this collective loss of memory the people here are suffering is a symptom of the denial of trauma. The scattered collectivity in Darwish's "The Owl's Night" resembles the people in Tuffaha's "Kaan's Sister Saar," who "forget/or walk around as if they had forgotten." At times, when people subjected to a traumatizing experience get overly frightened, they repress the experience of trauma. However, the holocaust historian, Saul Friedlander, who stressed the role of "collective memory" in order for healing to take place, points out that "the truth can be recovered, and psychological equanimity restored... only when memory comes" (qtd in Alexander, 5). 
If it takes memory, both personal and collective, for the healing process to take place, it is interesting that throughout his life Darwish has acted as the memory of the Palestinian people; his prolific literary work about his homeland attests to the truth that it was his life-long vocation to treasure the Palestinian history. In the words of Lena Khalaf Tuffaha, Mahmoud Darwish is one of "the keepers of Palestine's memory."

\section{Conclusion}

In this paper, I have attempted to explore the Arab identity of two poets, Mahmoud Darwish and Lena Tuffaha, through the lens they perceived themselves- one of a lost homeland. I have drawn on several self- theories in order to illuminate the multi-dimensional facets of their identities. I have also made use of the motifs of time and place for the same purpose. An analytical study of some of their works have shown that Darwish and Tuffaha share sentiments of a wounded national identity, therefore an insistence on self-identification through a deep bond with the land. The study has also shown that the works of the two poets bear similarities with regard to their perception of time. 


\section{Works Cited}

Abrams, Dominic, and Michael A. Hogg. Social Identity Theory: Constructive and Critical Advances. Harvester Wheatsheaf, 1990.

Ahmed, Hamoud, and Ruzy Hashim. "Resisting Colonialism through Nature: An Ecopostcolonial Reading of Mahmoud Darwish's Selected Poems." Holy Land Studies, vol. 13, no. 1, 2014, pp. 89107.

Alexander, Jeffery C., et al. Cultural Trauma and Collective Identity. University of California Press, 2004.

Austrian, Sonia. Developmental Theories Through the Life Cycle. Columbia University Press, 2008.

Darwish, Mahmoud. "Antithesis." Journal of Arabic Literature, translated by George El-Hage, 2005, vol. 36, no. 1, pp. 50-51.

---. "Identity Card." Splinters of Bone: Poems. Translated by B. M. Bennani, Greenfield Review Press, 1974, pp. 13-14.

---. "The Owl's Night." Why Did You Leave the Horse Alone? Translated by Jeffrey Sacks, Archipelago Books, 2006, p. 22.

---. "Who Am I After the Stranger's Night?" If I Were Another: Poems. Translated by Fady Joudah, Farrar, Straus and Giroux, 2009.

Erikson, Erik. Identity, Youth, and Crisis. W. W. Norton, 1968.

Fanon, Frantz. The Wretched of the Earth. Translated by Richard Philcox, Grove Press, 1963.

Farhat, Zahraa. "Arab-American Poet Finds Inspiration in her Heritage." The Arab American News, 25 Aug. 2018, arabamericannews.com/2017/08/25/arab-american-poet-findsinspiration-in-her-heritage/

Ghanim, Honaida. "The Urgency of a New Beginning in Palestine: An Imagined Scenario by Mahmoud Darwish and Hannah Arendt." College Literature, vol. 38, no. 1, 2011, pp. 75-94.

Habib, Maha F. "Writing Palestinian Exile: The Politics of Displacement in the Narratives of Mahmoud Dawish, Mourid Barghouti, Raja Shehadeh and Fawaz Turki." Holy Land Studies, vol. 12, no. 1, 2013, pp. 71-90.

Hamzah, Hussain. "The Image of the Mother in the Poetry of Mahmoud Darwish." Holy Land Studies, vol. 8, no. 2, 2009, pp. 159-194. 
Hermans, Hubert. Assessing and Stimulating a Dialogical Self in Groups, Teams, Cultures and Organizations, Springer International Publishing Switzerland, 2016.

---. "The Construction and Reconstruction of a Dialogical Self." Journal of Constructivist Psychology, no. 16, 2003, pp. 89-130.

---. "Dialogical Self Theory and the Increasing Multiplicity of I-Positions in a Globalizing Society: An Introduction." New Directions for Child and Adolescent Behaviour, no. 137, 2012, pp. 1-21.

Hermans, Hubert and Agnieszka Hermans-Konopka. Dialogical Self Theory: Positioning and Counter-Positioning in a Globalizing Society. Cambridge University Press, 2010.

Hoare, Carol Hren. Erikson on Development in Adulthood: New Insights from the Unpublished Papers. Oxford University Press, 2002.

Hughes, Luther. "'I belong to many places': A Q\&A with Washington State Book Award winner Lena Khalaf Tuffaha." The Seattle Times, 21 Dec. 2018, seattletimes.com/entertainment/books/i-belong-tomany-places-a-qa-with-washington-state-book-award-winnerlena-khalaf-tuffaha/

Irving, Sarah. "Nostalgia with a Political Edge." The Electronic Intifada, 25 Jul. 2017, electronicintifada.net/content/nostalgia-politicaledge/21191

Mena, Erica. "The Geography of Poetry: Mahmoud Darwish and Post National Identity." Human Architecture: Journal of the Sociology of Self-Knowledge, vol. 7, no. 5, 2009, pp. 111-117.

Sazzad, Rehnuma. Edward Said's Concept of Exile: Identity and Cultural Migration in the Middle East. I.B. Tauris, 2017.

Siddiq, Muhammad. "Significant but Problematic Others: Negotiating "Israelis" in the Works of Mahmoud Darwish." Comparative Literature Studies, vol. 47, no. 4, 2010, pp. 487-503.

Tuffaha, Lena Khalaf. “Immigrant.” Water \& Salt, Red Hen Press, 2017, pp. 22-23.

---. “Kaan's Sister Saar." Michigan Quarterly Review, vol. 57, no. 2, 2018, p. 222.

---. "Linger." The James Franco Review, 27 May 2015, no. 3, thejamesfrancoreview.com/2015/05/27/two-poems-by-lenakhalaf-tuffaha/ 
---. "Notes on the Nature and Implications of Kaan." Michigan Quarterly Review, vol. 57, no. 2, p. 219.

---. "Upon Arrival." Water \& Salt, Red Hen Press, 2017, p. 15.

Wasserstein, David J. "Prince of Poets." American Scholar, vol. 81, no. 4, 2012, pp. 111-117.

Yeshurun, Helit. "'Exile Is So Strong Within Me, I May Bring It to the Land' A Landmark 1996 Interview with Mahmoud Darwish." Journal of Palestine Studies, vol. 42, no. 1, 2012, pp. 46-70. 